\title{
HUKUM PIDANA DAN KAITANNYA DENGAN PENGGUNAAN MEDIA SOSIAL
}

\author{
Natasya Serepina Parhusip*) \\ Fakultas Hukum, Universitas Kristen Indonesia
}

\begin{abstract}
To date the growing use of technology is evidenced by the mushroomed of of a good number of social media such as Facebook, Twitter, Path, MySpace and so on. The public response towards the existence of the social media can be seen in the increasing number of social media users. Utilizing social media, everyone has freedom to express themselves through activities on the internet such as making comments and uploading various things. Despite its advantages, social media has sometimes become a stumbling block for users. One of the frequent issues arising in the usage of social media is offensive acts as a result of the activities in the social media. Therefore, the knowledge as to what extent users can express its aspiration in the social media is important which is strongly related to the law education to public. This paper elaborates cases of offensive acts occurred in the social media which are considered against the law particularly in Indonesian contexts. This paper further tries to analysis the relationship between the rule of criminal law and the cyberlaw in Indonesia.
\end{abstract}

\section{Kata kunci : Hukum Pidana dan Media sosial}

\section{Pendahuluan}

Dewasa ini penggunaan teknologi semakin berkembang dengan pesat yang antara lain ditandai dengan semakin meningkatnya penggunaan media sosial seperti Facebook, Twitter, Path, MySpace dan sejenisnya. Bertumbuhnya jumlah media sosial tersebut direspon dengan meningkatnya jumlah pengguna (user) yang mengindikasikan tingginya animo masyarakat dalam penggunaan teknologi.

Media sosial adalah salah satu sarana sosialisasi masyarakat melalui internet atau dunia maya (virtual). Sama seperti sarana sosialisasi dalam dunia riil, maka dalam media sosial setiap orang memiliki kebebasan untuk mengekspresikan diri melalui aspirasi, opini, masukan yang biasa disebut „,comment ${ }^{\text {ec }}$ atau komentar dalam media sosial dimaksud, di samping memberikan komentar, para pengguna atau users juga dapat melakukan unggahan atau uploading dan melakukan unduhan atau downloading atas berbagai gambar maupun suara.

Salah satu yang menjadi isu dalam penggunaan media sosial adalah sejauh mana pengguna dapat memberikan komentar-komentar atau tulisan dan informasi lainnya sehingga tidak menyinggung orang lain, mengganggu kenyamanan orang lain dan bahkan dianggap

\footnotetext{
${ }^{*)}$ Dosen Tidak Tetap Fakultas Hukum UKI Jakarta
}

melakukan pencemaran nama baik. Terkait dengan hal tersebut masalah yang kerap mengemuka terkait batasan dimaksud adalah pencemaran nama baik yang erat kaitannya dengan penggunaan media sosial. Walaupun telah ada pengaturan dalam hukum pidana terkait dengan pencemaran nama baik, namun tidak semua pengguna memahami aturan-aturan dimaksud mengenai kebebasan mengungkapkan pendapat dan melakukan berbagai hal di halaman media sosial. Untuk itu perlu dikaji lebih lanjut aturan hukum pidana dan kaitannya dengan Undang-Undang RI No. 11 Tahun 2008 Tentang Informasi dan Teknologi (UU ITE) serta implementasinya di Indonesia.

Tulisan ini menggali batasan-batasan dalam mengekspresikan aspirasi dimaksud dalam konteks hukum dan peraturan terkait UU ITE di Indonesia. Pemahaman akan konteks hukum dan peraturan sangat diperlukan dalam rangka menjawab pertanyaan dalam tulisan ini khususnya terkait hubungan antara kebebasan berekspresi atau berpendapat dan tindakan yang bersifat pidana.

\section{Permasalahan}

Bagaimana kaitan antara hukum pidana dengan penggunaan media sosial? 


\section{Tujuan Penulisan}

Untuk mengetahui keterkaitan hukum pidan dengan penggunaan media sosial di masyarakat.

\section{Media Sosial dan Kebebasan Berpendapat}

Kebebasan berpendapat baik dalam bentuk lisan maupun tulisan merupakan citacita hampir semua orang menginginkannya agar hal itu terwujud, terlebih di masysrakat. Sangat mahal dan berharganya kebebasan berpendapat ini, sampai-sampai harus diperjuangkan dengan cucuran keringat dan darah. Bahkan, hampir di semua negara, kebebasan berpendapat ini dijamin di dalam undangundang. Namun kebebasan berpendapat ini dapat disalahartikan, yang pada akhirnya merugikan orang lain bahkan negara sekalipun yaitu dengan menuduhkan sesuatu yang tidak memiliki dasar atau yang sering kita dengar sebagai pencemaran maupun penghinaan. Adapun sarana yang digunakan di kebanyakan masyarakat adalah media cetak, elektronik, dan sekarang ini dikenal dengan media sosial.

Media sosial adalah sejenis media yang digunakan dengan membolehkan para pengguna dengan mudah untuk menyertai, berkongsi, dan mencipta isi meliputi blog, rangkaian sosial, wiki, forum dan dunia virtual. Blog, rangkaian sosial dan wiki merupakan bentuk media sosial yang paling umum digunakan oleh masyarakat di seluruh dunia. ${ }^{1}$ Media sosial juga disebut sebagai sarana diskursus online dimana pengguna dapat berkreasi seperti mengisi konten, membaginya, dan menyiarkannya dalam jaringan internet. ${ }^{2}$ Media sosial merupakan sarana penggunaan teknologi internet dimana individu dan komunitas dapat membagi, menciptakan, mendiskusikan dan memodifikasi isi yang dihasilkan oleh pengguna yang merupakan sarana komunikasi yang baru di era ini. $^{3}$

\footnotetext{
${ }^{1}$ http://ms.wikipedia.org/wiki/Media_sosial (Jum ${ }^{\text {ee }}$ at 9 januari 2015 jam 19.20)

${ }^{2}$ Asur, Sitaram \& huberman, Bernardo, A. Predicting the Future with Social Media, Web Intelligence and Intelligent Agenct Technology (WI-IAT), Vol. 1, pp. 492-499

3 Kietzmann, Jan H, Hermkens, K, McCarthy, I P, Silvestre, Bruno, S, 2011, „Social media? Get serious! Understanding the functional building blocks
}

Berdasarkan berbagai definisi tersebut di atas, hakikat dari media sosial adalah suatu tempat dimana pengguna bebas berekspresi dengan memuat tulisan-tulisannya bahkan melakukan perikatan di internet atau lebih tepatnya di berbagai media sosial yang ada. Melalui media sosial, kebebasan berpendapat dari masyarakat banyak yang teraspirasi yang menjadi suatu manfaat bagi pengguna dalam menggunakan media sosial.

Dari berbagai kelebihan media sosial, salah satu yang menarik adalah media sosial bermanfaat menjadi sarana atau ajang berkreasi dimana para pengguna media sosial dapat menulis berbagai hal di halaman media sosialnya, memberikan komentar bahkan mengupload gambar/ foto, video di dalamnya dan melakukan percakapan (chatting) dengan teman temannya di akunnya tersebut. Biasanya dalam konteks inilah sering terjadi atau muncul kasus kasus yang pada akhirnya menyeret si pelaku yang mempunyai akun media sosial tersebut. Sebagai ajang berkreasi, kebebasan berpendapat pengguna banyak digunakan yang jika tidak berhati-hati berpotensi pada tindakan pencemaran nama baik atau penghinaan terhadap seseorang.

Adapun yang menjadi kekurangan-kekurangan dalam penggunaan media sosial antara lain aksesibilitas yang tinggi yang dapat dilakukan oleh siapa saja dapat merugikan kelompok tertentu. Misalnya, media sosial yang diakses secara bebas oleh anak-anak dapat membahayakan yang belum memahami risiko penggunaan media sosial, dan kemungkinan dapat terjadi adanya pemalsuan identitas terkait adanya informasi yang tidak benar/akurat di akun media sosial seseorang.

\section{Sistem Hukum Indonesia dan Media sosial}

Ekspresi dan batasan-batasan yang dimiliki pengguna media sosial banyak dipengaruhi oleh sistem hukum di Indonesia. Mencermati sistem hukum di Indonesia, maka setiap pengguna media yang beroperasi dalam konteks sistem hukum dimaksud harus memahami sumber hukum antara lain undang-undang yang menjadi sumber hukum formal utama dan peraturan terkait seperti peraturan, keputusan dan vonis.

of social media"e, Business Horizons, Vol. 54, pp. 241-251 
Adapun hukum yang erat dengan kaitan penggunaan media sosial adalah hukum siber atau cyber law dan hukum pidana. Dalam konteks hukum tersebut maka dapat diketahui batasan sejauh mana seseorang yang berekspresi dan berpendapat memiliki batasan yang telah diatur baik secara umum maupun secara khusus.

\section{Hukum Siber dan Media Sosial}

Hukum Siber (Cyber Law) adalah istilah hukum yang terkait dengan pemanfaatan teknologi informasi. Hukum siber yang berlaku di Indonesia adalah Undang-Undang RI No.11 Tahun 2008 Tentang Informasi dan Transaksi Elektronik (selanjutnya disingkat UU ITE). Berdasarkan Pasal 1 UU ITE dikatakan bahwa Informasi Elektronik adalah satu atau sekumpulan data elektronik, termasuk tetapi tidak terbatas pada tulisan, suara, gambar, peta, rancangan, foto, electronic data interchange (EDI), surat-surat elektronik (electronic mail), telegram, teleks, telecopy atau sejenisnya, huruf, tanda, angka, Kode Akses, simbol, atau perforasi yang telah diolah yang memiliki arti atau dapat dipahami oleh orang yang mampu memahaminya. Berdasarkan isi pasal ini, maka dapat disimpulkan bahwa informasi elektronik memiliki jangkauan pengertian yang sangat luas dan kompleks.

Esensi dari hukum siber tersebut adalah bahwa segala aktivitas di dunia maya yang dilakukan di Indonesia harus mengikuti ,aturan main ${ }^{\text {ee }}$ yang tertuang dalam hukum dimaksud, tidak terkecuali penggunaan media sosial. Disinilah letak titik kritis dimana kebebasan berpendapat seseorang dalam dunia maya dibatasi oleh aturan main dimaksud.

Dalam UU ITE ini dijelaskan dan ditegaskan dalam Pasal 5 bahwa ia mengakui keberadaan dari bukti elektronik. Berbicara bukti elektronik ini, maka disamping pada UU ITE terdapat juga antara lain dalam Undang-Undang RI No. 8 Tahun 1997 tentang Dokumen Pe-rusahaan. Dari aturan yang ada tersebut, maka dapat disimpulkan bahwa bukti elektronik dapat digunakan sebagai alat bukti yang sah dan telah diakui sebagai alat bukti.

Perihal sanksi pidana tertuang dalam Pasal 45 - 52 UU ITE. Khusus mengenai pence- maran nama baik dan penghinaan dapat kita lihat dalam Pasal 45 (3) UU ITE dimana disana dikatakan bahwa sanksi terhadap pencemaran nama baik dan penghinaan adalah penjara maksimal 6 tahun dan atau denda paling banyak Rp. 1.000.000.000,00(satu milyar rupiah).

\section{Hukum Pidana dan Penggunaan Media So- sial}

Akhir-akhir ini, masyarakat Indonesia banyak menggunakan media sosial sebagai sarana untuk keperluan pribadi mau-pun bisnis. Tapi banyak juga yang menggunakan media sosial untuk kepentingan-kepentingan yang tak perlu, seperti membuat pernyatanpernyataan yang dapat merugikan bahkan mencemarkan nama baik orang lain. Bila hal itu terjadi, media sosial telah menjadi sarana untuk melakukan tindak pidana berupa pencemaran nama baik atau penghinaan. Untuk itu, pemerintah merasa perlu untuk melindungi setiap warga negara. Indonesia sebagai negara hukum telah memiliki hukum pidana yang di dalamnya mengandung ketentuan-ketentuan untuk melindungi nama baik dan kehormatan.

Sejalan dengan penggunaaan media sosial, hukum pidana berlaku khususnya terkait dengan pencemaran nama baik atau halhal pidana terkait lainnya yang diakibatkan dari penggunaan media sosial.

Menurut Eddy OS, fungsi umum hukum pidana adalah untuk menjaga ketertiban umum, sedangkan fungsi khusus hukum pidana selain untuk melindungi kepentingan hukum juga memberi keabsahan bagi negara dalam rangka menjalankan fungsi melindungi kepentingan hukum. ${ }^{4}$

Ketika seseorang melakukan suatu tindak pidana, maka yang bersangkutan harus bertanggung jawab akan perbuatannya itu. Pertanggungjawaban pidana diartikan sebagai suatu kewajiban untuk membayar pembalasan yang akan diterima pelaku dari diri seseorang yang telah dirugikan. ${ }^{5}$

\footnotetext{
${ }^{4}$ Eddy OS Hiariej, Prinsip-Prinsip Hukum Pidana, Yogyakarta : Cahaya Atma Pustaka 2014, hal. 29

5 Rouscoe Pound, "An Introduction to the Philosophy of Law" dalam Romli Atmasasmita, Perbandingan
} 
Dalam KUHP pencemaran nama baik diistilahkan sebagai penghinaan terhadap seseorang, terdapat dalam Bab XVI, Buku II KUHP khususnya pada Pasal 310 ayat (1) dan (2), Pasal 311 ayat (1) dan Pasal 318 ayat (1) KUHP. Penghinaan itu harus dilakukan dengan cara menuduh seseorang telah melakukan perbuatan yang tertentu dengan maksud tuduhan itu akan tersiar (diketahui orang banyak). ${ }^{6} \mathrm{Da}-$ ri pendapat ini, maka dapat diambil kesimpulan bahwa terdapat unsur penting dari penghinaan disini, yaitu "dengan cara menuduh" dan "agar berita itu tersiar".

Arti kata menuduh dapat diartikan membeberkan cerita yang tidak benar dengan cara menyiarkannya baik secara lisan maupun tulisan. Ketika kita berbicara secara tertulis maka dapat dibagi lagi menjadi tertulis d iatas kertas atau tertulis di dunia maya (dunia virtual).

R. Soesilo menjelaskan yang dimaksud dengan "menghina", yaitu "menyerang kehormatan dan nama baik seseorang”. „Kehorma$\tan ^{\text {ee }}$ yang diserang disini hanya mengenai kehormatan tentang ,nama baik ${ }^{\text {ee }}$, bukan ,kehormatan ${ }^{\text {ee }}$ dalam lapangan seksual. ${ }^{7}$ Berdasarkan statement ini, maka dapat diambil kesimpulan bahwa kata menghina disini mempunyai pengertian yang sangat luas. Bahkan kata „menghina $^{\text {ee }}$ ini dapat pula merujuk pada pengupload-an atau mengunduh gambar gambar orang lain dengan cara diedit secara tidak senonoh.

\section{Kaitan Hukum Siber dan Hukum Pidana}

Apabila dikaitkan dengan penggunaan media sosial, maka pasal KUHP (hukum pidana) dimaksud dapat disandingkan dengan beberapa pasal UU ITE (hukum siber) yang mengaitkan perbuatan-perbuatan terlarang dalam informasi dan transaksi elekronik yang apabila dilanggar akan dikenakan hukum pidana.

Perbuatan-perbuatan tertentu terlarang yang dikaitkan ketentuan pidana adalah perbu-

Hukum Pidana, Bandung : Mandar-Maju, 2000, hal. 65.

${ }^{6}$ R. Soesilo, Kitab Undang-Undang Hukum Pidana (KUHP) Serta Komentar-Komentarnya Lengkap Pasal Demi Pasal, Bogor : Politeia, 1995, hal. 226.

${ }^{7}$ Ibid, hal. 226. atan yang merugikan orang lain antara lain menyangkut pencemaran nama baik dan penyebaran rasa kebencian atau isu sara khususnya Pasal 27 (3) UU ITE, Pasal 28 UU ITE, Pasal 36 UU ITE.

\section{Penyuluhan Hukum Bagi Masyarakat}

Indonesia adalah negara hukum. Artinya, hukum harus dapat melindungi setiap individu warga negara dari ancaman kejahatan yang menyangkut nyawa, harga benda, kesusilaan, kehormatan, serta nama baik. Oleh karena itu, hukum harus dapat dirumuskan sedemikian rupa agar kepentingan-kepentingan tersebut tidak dicemari atau diganggu. Hal ini sangat penting, karena di dalam pergaulan masyarakat kenyataan tersebut dapat terjadi dan dapat menimpa setiap orang tanpa kecuali. Berkaitan dengan hal itu, negara harus hadir memberi perlindungan agar setiap orang diberi kenyamanan maupun kebebasan untuk menuangkan pikiran atau pendapatnya, namun tidak merusak serta mencemari kehormatan dan nama baik orang lain. Di sinilah dapat diwujudkan bahwa hukum bertujuan untuk mengatur dan melindungi masyarakat dari segala hal-hal yang merugikan.

Hukum sangat penting bagi kehidupan masyarakat karena hukum mengatur hubungan antara anggota masyarakat yang satu dengan yang lain, tidak terkecuali mengatur hubungan antara anggota masyarakat yang satu dengan yang lain, tidak terkecuali mengatur hubungan antara anggota masyarakat dengan anggota masyarakatnya. ${ }^{8}$

Hukum mempunyai tugas untuk menjamin adanya kepastian hukum dalam masyarakat dan Selain itu, hukum menjaga dan mencegah agar setiap orang tidak menjadi hakim atas dirinya sendiri, tidak mengadili dan menjatuhkan hukuman terhadap setiap pelanggaran hukum terhadap dirinya. Namun setiap perkara harus diselesaikan melalui proses pengadilan, dengan perantaraan hakim berdasarkan ketentuan yang berlaku. ${ }^{9}$

\footnotetext{
${ }^{8}$ Arus Akbar Silondae \& Wirawan B Llyas, PokokPokok Hukum Bisnis, Jakarta : Salemba Empat 2011, hal. 1-2

${ }^{9}$ C.S.T Kansil, Pengantar Ilmu Hukum dan Tata Hukum Indonesia, Jakarta : Balai Putaka 1986, hal. 45
} 
Berdasarkan apa yang dikemukakan oleh C.S.T Kansil tersebut di atas, maka dapat di-tarik kesimpulan bahwa hukum merupakan se-suatu yang sangat penting bagi masyarakat agar tercipta keadilan dan dengan adanya hukum diharapkan tidak terdapat hukum rimba. Selain itu, disinipun hendak mengatakan bahwa apabila terjadi sengketa maka ada jalur yang dapat ditempuh yaitu jalur pengadilan dan bukan malah main hakim sendiri.

Pengertian hukum sebagai norma dapat dirumuskan sebagai himpunan petunjuk hidup yang mengatur tata tertib dalam suatu masyarakat, dan seharusnya ditaati oleh anggota masyarakat yang bersangkutan. ${ }^{10}$

Penyuluhan hukum adalah sistem kegiatan yang tujuan utamanya untuk menjadikan masyarakat sadar hukum. Pasal 2 dari Peraturan Menteri Hukum dan Hak Asasi Manusia RI Nomor M.01-PR.08.10 Tahun 2006 tentang Pola Penyuluhan Hukum, menegaskan bahwa: ${ }^{11}$

Penyuluhan hukum diselenggarakan dengan tujuan mewujudkan kesadaran hukum masyarakat yang lebih baik sehingga setiap anggota masyarakat menyadari dan menghayati hak dan kewajibannya sebagai warga negara dan mewujudkan budaya hukum dalam sikap dan perilaku yang sadar, patuh, dan taat terhadap hukum serta menghormati hak asasi manusia.

Berdasarkan Pasal 2 dari Peraturan Menteri Hukum dan Hak Asasi Manusia RI Nomor M.01-PR.08.10 Tahun 2006 tentang Pola Penyuluhan Hukum, maka dapat diambil kesimpulan bahwa penyuluhan hukum merupakan sesuatu yang sangat penting untuk dilakukan agar masyarakat sadar akan hukum serta menciptakan ketertiban di dalam masyarakat. Keti-

\footnotetext{
${ }^{10}$ Johanes Ibrahim \& Lindawati Sewu, Hukum Bisnis (Dalam Persepsi Manusia Modern), Bandung : Refika Aditama 2003, hal. 9-10

${ }^{11}$ http://www.google.com/url?q=http://perpustakaan. bphn.go.id/index.php/searchkatalog/downlo ad Data byId/12423/DAMPAKPENYULUHANHUKUMTE RHADAPTINGKATKESADARANHUKUMMASY ARAKAT.pdf\&sa=U\&ei=20-1VOOKJMq_uASxkY D4Bw\&ved=0CBkQFj AB\&sig2 = PHaL7BcE5mX8 rIHlgsibw\&usg=AFQjCNFVWGWH4atfdGLSwNa m9E08A0c 1A, Hlm 10, Tgl 14 Januari 2015, Jam 24.43
}

ka berbicara mengenai penyuluhan hukum ini, maka ada langkah-langkah yang dapat ditempuh untuk melakukan penyuluhan hukum ini. Penyuluhan hukum dilakukan melalui dua metode yaitu : ${ }^{12}$

(1) Penyuluhan hukum langsung yaitu kegiatan penyuluhan hukum yang dilakukan secara langsung yakni penyuluh hukum berhadapan dengan masyarakat yang disuluh, dapat berdialog dan bersambung rasa seperti misalnya ceramah, diskusi, saresehan, temu wicara, peragaan, simulasi, dan lain-lain; dan

(2) Penyuluhan hukum tidak langsung adalah kegiatan penyuluhan hukum yang dilakukan secara tidak langsung, yakni penyuluh hukum tidak berhadapan dengan yang disuluh, melainkan melalui media atau perantara, dalam hal ini media bahan bacaan berupa spanduk, leaflet, dan stiker.

Memahami hal tersebut, penyuluhan hukum bagi setiap individu warga masyarakat dibutuhkan untuk mengetahui hak dan kewajibannya dalam hukum, terlebih batasanbatasan dan larangan-larangan mengenai perlindungan nama baik. Selain itu, penyuluhan hukum menjadi sarana agar efektivitas hukum dapat diukur.

Penyuluhan hukum ini sangat penting dilakukan agar masyarakat dapat terinformasikan mengenai berbagai aturan aturan hukum yang ada, hal ini disebabkan karena tidak semua orang mengetahui hukum yang ada dan apa pentingnya mentaati hukum yang berlaku tersebut. Dengan pengetahuan akan hukum atau bekal hukum yang cukup, diharapkan masyarakat lebih bijaksana dalam pemantaatan media sosial.

\section{Analisis Permasalahan dalam Konteks Hu- kum di Indonesia}

Masyarakat kerap tidak menyadari secara komprehensif mengenai konsekuensi dari tindakan pidana khususnya terkait pencemaran nama baik. Banyak yang berasumsi bahwa dengan memiliki akun sendiri dalam media so-

\footnotetext{
${ }^{12} \mathrm{http}: / / p p m . l p p m . u p i . e d u / d e t a i l / 401 / p e n y u l u h a n-h u-$ kum-dan-ham-untuk-perlindungan-hak-hak-perempuan-dalam-rumah-tangga-di-kecamatan-dayeuhkolot-kabupaten-bandung, tgl 14 Januari 2015, jam 00.13
} 
sial maka mereka telah memiliki kebebasan penuh untuk mengungkapkan, mengunggah (uploading) dan bahkan menulis berbagai hal pada akun mereka sendiri, tanpa mencermati batasan-batasan yang sesungguhnya ada yang akhirnya membawa persoalan-persoalan dan gugatan-gugatan.

Uraian di atas menunjukkan banyaknya kasus yang tampil dipermukaan dan menjadi sorotan. Adapun beberapa contoh kasus yang ada yaitu antara lain :

1. Kasus Antara Prita dan Rumah Sakit Omni "Seperti halnya kasus pencemaran nama baik yang menimpa Prita Mulyasari dengan rumah sakit Omni Internasional. Berawal pada tanggal 15 Agustus 2008, pada saat itu Prita mengirimkan email yang berisi keluhan atas pelayanan yang diberikan pihak rumah sakit ke customer_care@bank sinarmas. com dan kepada kerabatnya yang lain dengan judul "Penipuan Omni Internasional Hospital Alam Sutera Tangerang". Pada tanggal 30 agustus 2008 Prita kembali mengirimkan isi emailnya tersebut kepada pembaca detik. com. Rumah sakit Omni Internasional yang membaca isi email Prita tersebut mengajukan gugatan pidana ke direktorat reserse kriminal khusus. Prita Mulyasari ditahan di lapas wanita Tangerang dan harus diadili di Pengadilan Tangerang terkait kasus pidana yang dilaporkan oleh rumah sakit omni internasional. Pihak Rumah Sakit Omni International tidak dapat menerima keluhan Prita yang dikirim kepada temannya melalui email karena dianggap telah mencemarkan nama baiknya." 13

2. Kasus Penghinaan yang dilakukan Florence Sihombing. Florence membuat heboh Stasiun Pengisian Bahan Bakar Umum (SPBU) di wilayah Baciro/Lempuyangan, Yogyakarta pada Rabu, 27 Agustus 2014. Wanita berusia 26 tahun ini marah-marah ka rena dianggap tidak mau antri saat hendak mengisi bahan bakar minyak (BBM). Ketika itu ia yang mengendarai sepeda motor masuk ke jalur mobil di bagian Pertamax 95. Kekesalan Florence pun diungkapkan melalui akun Path miliknya de-

\footnotetext{
${ }^{13}$ http://www.indosiar.com/fokus/karena-kirim-emailprita-ditahan_80556.html, diakses tanggal 24 agustus 2011.
}

ngan kalimat memaki-maki Kota Pelajar tersebut. "Jogja miskin, tolol, dan tak berbudaya. Teman-teman Jakarta-Bandung jangan mau tinggal Jogja," tulis Florence dalam Path@florenceje, Kamis 28 Agustus 2014.

Makian melalui status di media sosial itu langsung tersebar di dunia maya. Kicauan dalam akun Path tersebut menuai umpatan di berbagai media sosial. Beberapa waktu kemudian, Florence meminta maaf atas kata-katanya. Screenshot permintaan maafnya itu diposting oleh akun Twitter @swaraga-mafm Kamis, 28 Agustus 2014 pukul 8:36 AM dalam bentuk attachment image, yakni "Florence Sihombing memohon maaf yang sebesar-besarnya kepada masyarakat Jogja via akun Pathnya juga. \#FlashBreak." Akan tetapi, faktanya adalah bahwa nasi telah menjadi bubur. Walau telah meminta maaf di beberapa media sosial dan menggelar konferensi pers melalui pengacaranya, Florence ternyata tetap diproses secara hukum. Terutama dengan adanya gugatan dari sejumlah komunitas di Yogyakarta. ${ }^{14}$

Kedua kasus tersebut adalah kasus penggunaan media sosial yang berujung pada proses pengadilan (tuntutan pidana). Kasus tersebut sesungguhnya mengindikasikan bahwa walaupun dewasa ini kebutuhan akan media sosial sangat tinggi namun ternyata media sosial membawa dampak-dampak negatifnya selain dampak yang positifnya bagi penggunanya.

Adapun penyebabnya apabila dikaji dari perspektif hukum utamanya adalah para pengguna media sosial belum memahami secara utuh bahwa dalam konteks hukum di Indonesia walaupun setiap orang memiliki kebebasan untuk menulis di halaman media sosial mere$\mathrm{ka}$, namun terdapat pembatasan pembatasan sebagaimana tercantum dalam aturan hukum yang berlaku seperti hukum pidana dan hukum siber (cyber law).

Konsekuensi hukum dari penggunaan media sosial telah tersurat dari berbagai peraturan terkait penggunaan media sosial dan erat kaitannya dengan hukum pidana. Pertama, berbagai tulisan, gambar atau apapun yang diunggah (di-upload) dalam media sosial atau dunia virtual tersebut dapat dijadikan alat bukti. Hal ini sebagaimana tercantum dalam Pasal 5 UU ITE. 
Seperti yang kita ketahui bila berbicara alat bukti, maka berdasarkan pasal 184 KUHAP, alat bukti yang sah adalah : (1) Keterangan saksi, (2) keterangan ahli, (3) surat, dan (4) petunjuk, dan (5) keterangan terdakwa. Dalam perkembangan selanjutnya kini muncullah bukti elekronik pula demi menciptakan adanya suatu kepastian hukum, karena seperti yang kita ketahui dewasa ini tingkat kebutuhan akan dunia virtual atau dunia cyber sangat tinggi. Tingkat kebutuhan yang tinggi tersebut bukan saja untuk menghabiskan waktu luang, tetap juga untuk bekerja dan melakukan banyak transaksi transaksi lainnya.

Kedua, ada batasan terkait kebebasan berpendapat dimana suatu aktivitas dalam media sosial dapat dikategorikan pelanggaran. Adapun berbagai macam jenis pelanggaranpelanggaran yang diatur dalam UU ITE dapat ditemui dalam berbagai pasal antara lain Pasal 27-37 UU ITE. Salah satu Pasal yang membahas mengenai pencemaran nama baik dan penghinaan adalah sebagaimana yang kita jumpai pada Pasal 28 UU ITE yang mengatakan : "Setiap Orang dengan sengaja dan tanpa hak menyebarkan berita bohong dan menyesatkan yang mengakibatkan kerugian konsumen dalam Transaksi Elektronik." Apabila dilihat Pasal 28 UU ITE maka dapat diambil kesimpulan bahwa pasal ini mengatur mengenai kerugian yang akan diterima oleh produsen, dalam hal ini bila dikaitkan dengan kasus Florance maka kerugian yang dimaksud adalah kerugian yang di terima oleh SPBU.

Dalam UU ITE juga dibahas mengenai sanksi yang diberikan seputar persoalan persoalan pelanggaran pelanggaran yang terkait dengan pencemaran nama baik, penghinaan maupun pelanggaran terkait lainnya, sebagaimana diatur dalam Pasal 45-52 UU ITE menyangkut Ketentuan Pidana.

Apabila kita lihat Pasal 45 UU ITE, maka dapat dikatakan bahwa sanksi pidana penjara minimal adalah 6 Tahun dan maksimal 12 tahun, sedangkan denda minimal Rp. 1.000. 000.000,00 (satu milyar rupiah)- Rp. 2.000. 000.000,00 (dua milyar rupiah). Sanksi pidana lainnya minimal dan maksimalnya dapat berbeda beda tergantung pelanggaran yang dilakukan. Sedangkan berdasarkan Pasal 27 UU ITE, dapat diambil kesimpulan bahwa walau- pun setiap orang mempunyai kebebasan untuk menulis dan men-share segala sesuatu di media sosial terutama kepunyaannya sendiri, namun semua itu ada pembatasannya dan ada larangan-larangan yang terkait dengan hal-hal tersebut.

\section{Kasus Pidana Terkait Penggunaan Media Sosial}

Di dalam masyarakat yang demokratis seperti Indonesia, menyampaikan pikiran dan pendapat secara lisan maupun tulisan dibenarkan dan dilindungi. Namun kadangkala penyampaian pikiran dan pendapat tersebut, sering menyebabkan tercemar dan terhinanya nama baik seseorang. Dalam menyampaikan pikiran dan pendapat tidak jarang dan selalu ditemui apa yang disebut pencemaran dan penghinaan. Masalah ini kerap menjadi pemberitaan di media cetak dan elektronik, dimana hal itu berujung pada penyelesaian secara hukum. Pencemaran dan penghinaan adalah suatu perbuatan yang dilarang di muka hukum, khususnya hukum pidana dan UU RI tentang ITE. Pengaturan mengenai perlindungan terhadap nama baik dan kehormatan tentunya sesuatu yang sangat perlu, mengingat fitnah lebih kejam daripada pembunuhan itulah yang selalu kita dengar di masysrakat kita sebagai suatu pepatah yang telah puluhan tahun diajarkan di dalam masyarakat. Pernyataan mengenai keberadaan seseorang yang menjurus kepada penghinaan serta pencemaran adalah sesuatu yang menyakitkan, bahkan mengganggu ketenangan seseorang dimana dia tidak melakuka yang seperti yang dituduhkan. Oleh karena itu adanya undangundang yang mengatur ITE ini adalah sangat perlu bahkan harus ditegakkan, emngingat semakin banyaknya serta mudahnya orang menggunakan media sosial.

Sejalan dengan itu, pengekspresian secara bebas di media sosial ini dapat menimbulkan pencemaran nama baik ataupun penghinaan terhadap seseo-rang atau bahkan sekelompok orang dan menyebabkan yang bersangkutan mengalami kerugian. Disinilah pada akhirnya muncul masalah masalah yang pada akhirnya dibawa ke dalam ranah pengadilan. 
Seperti yang diuraikan di atas, hukum yang mengatur ,aturan main ${ }^{\text {ee }}$ penggunaan media sosial pada hakikatnya telah ada, namun masih seringnya terjadi kasus pidana terkait penggunaan media sosial sejatinya adalah indikasi masih minimnya pemahaman akan hukum yang berlaku dimaksud. Pencemaran nama baik maupun penghinaan yang dilakukan di media sosial atau bisa dikatakan dalam dunia maya ini jelas diatur dalam UU ITE, namun tidak semua orang mengetahui mengenai undang-undang ini.

Mengingat pengguna media sosial berasal dari berbagai kalangan dengan latar belakang antara lain tingkat pengetahuan yang berbeda-beda pula, maka perlu dipikirkan pula cara agar si pengguna media sosial atau dunia maya tersebut mengetahui atau setidaknya menyadari mengenai keberadaan aturan-aturan hukum yang terkait dengan dunia maya itu dan minimal mengetahui mengenai tindakan-tidakan yang bagaimana yang tidak diperkenankan atau tindakan-tindakan apa saja yang dapat merugikan orang lain yang dapat dikenakan sanksi.

Ketika kita berbicara mengenai pengguna sosial yang berbeda-beda kalangan dan umur ini, maka akan kita jumpai berbagai alasan mengapa mereka menulis secara sembarangan di dalam akun mereka. Untuk pengguna media sosial dikalangan anak-anak (dibawah umur) dan pengguna dewasa yang menggunakan akun media sosial ada beberapa alasan mengapa mereka menulis secara bebas :

1. Ketidakpahaman akan berbagai aturan hukum (bagi pengguna anak-anak dan dewasa);

2. Adanya persepsi/opini bahwa media sosial merupakan wahana untuk mengekspresikan diri sebebas bebasnya (bagi pengguna anak-anak dan dewasa);

3. Adanya persepsi/opini bahwa jika menulis atau meng-upload di media sosialnya (akun sendiri) kerahasiaan dapat terjamin (bagi pengguna anak-anak dan dewasa);

4. Ketidaksadaran akan perbuatan yang dilakukan. Maksudnya adalah bahwa mereka merasa bahwa apa yang mereka tulis atau upload di internet merupakan sesuatu yang biasa-biasa saja (bagi pengguna anak-anak dan dewasa);
5. Sebagai sarana untuk menyalurkan emosi mereka lewat media sosial. Adakalanya orang dewasa ini mereka stress dalam kerjaan mereka dan mereka menyalurkannya di media sosial (bagi pengguna dewasa);

6. Untuk menarik perhatian dimana menulis dan meng-upload di media sosial bahkan secara ekstrim sengaja dilakukan agar mendapat perhatian dari teman-temannya agar banyak yang mengomentarinya (bagi pengguna dewasa).

Berdasarkan alasan-alasan yang telah dikemukakan, ada poin yang menjadi sangat penting dan mempengaruhi poin-poin lainnya, yaitu yang terdapat dalam poin no 1, yang mengatakan bahwa: "ketidakpahaman pengguna akan aturan hukum". Akar segala konflik/permasalahan yang terkait pencemaran nama baik maupun penghinaan ini diakibatkan ketidakpahaman akan aturan hukum dan sanksi yang akan diberikan. Banyak orang yang tidak memahami aturan mengenai UU ITE terkait dunia maya tersebut, dan banyak pula orang yang tidak mengetahui bahwa yang namanya alat bukti kini sudah berkembang bukan lagi apa yang ada di dalam Pasal 184 KUHAP saja yang terdiri dari: (1) keterangan saksi, (2) keterangan ahli, (3) surat, (4) petunjuk, dan (5) keterangan terdakwa. Kalau dahulu alat bukti terbatas pada 5 poin ini, maka sekarang muncul apa yang dinamakan alat bukti elektronik. Perihal bukti elektronik ini lebih spesifik diatur dalam Pasal 5 UU ITE. Dari Pasal 5 UU ITE tegas disebutkan bahwa informasi elektronik dan/atau dokumen elektronik dan/atau hasil cetaknya adalah alat bukti hukum yang sah dan merupakan perluasan dari alat bukti yang terdapat dalam KUHAP. Pasal ini digunakan untuk mengakomodir kebutuhan alat bukti pada kasus cyber crime.

Minimnya pemahaman pengguna terkait aturan yang berlaku juga merefleksikan isu lain yang tidak kalah pentingnya, yakni efektivitas sosialisasi dan penyuluhan hukum yang dilakukan oleh Pemerintah. Disinilah tantangan bagi Pemerintah, jika penyuluhan/sosialisasi hukum telah dilakukan. Penyuluhan hukum tentunya bertujuan untuk memberikan pemahaman yang komprehensif atas hukum yang berlaku termasuk konsekuensi hukum dari se- 
seorang yang melakukan suatu tindakan. Tanpa efektivitas penyuluhan/sosialisasi hukum, maka kasus hukum akan berpotensi terus terjadi walaupun telah terdapat peraturannya.

\section{Kesimpulan}

Semakin meningkatnya aktivitas masyarakat di dunia maya (internet khususnya media sosial) yang merupakan dinamika era globalisasi saat ini belum memiliki manfaatnya secara optimal, dimana masih terdapat masyarakat yang terjerat kasus hukum atau mengalami kerugian dari penggunaan media sosial tersebut. Berbagai permasalahan yang ada dalam penggunaan media sosial yang pada akhirnya memiliki dampak hukum seperti pencemaran nama baik, lebih dikarenakan karena ketidaktahuan/ketidakpahaman masyarakat akan adanya pengaturan yang memberikan batasan atas penggunaan media sosial utamanya dalam mengekspresikan aspirasinya. Dengan kata lain, kasus-kasus yang terus menerus bermunculan walaupun telah ada payung hukumnya lebih dikarenakan oleh minimnya pema-haman akan aturan-aturan tersebut. Adapun implikasi dari tindakan pelanggaran dimaksud adalah sanksi pidana yang telah diatur dalam hukum pidana dan hukum siber yang berlaku di Indonesia khususnya UU ITE. Sama seperti peraturan yang telah ada, konsekuensi/implikasi hukum atas aktivitas yang dilakukan dalam media sosial juga tidak banyak dipahami oleh pengguna/masyarakat. Dengan semakin maraknya berbagai permasalahan hukum yang diakibatkan ketidaksadaran hukum tersebut mengindikasikan masih belum optimalnya atau efektifnya penyuluhan dan sosialisasi hukum berbagai peraturan terkait dunia maya dan rambu-rambu yang harus dipatuhi oleh para pengguna. Agar masyarakat dapat memperoleh manfaat optimal dari penggunaan media sosial, maka masyarakat perlu meningkatkan kesadaran akan hukum.

\section{Saran}

Para pengguna media sosial perlu lebih mengetahui dampak dari berbagai tindakan/aktivitas di media sosial terutama perbuatan-perbuatan yang melanggar. Pemerintah perlu lebih meningkatkan perannya dalam mengintensifkan penyuluhan dan sosialisasi mengenai aturan main bagi para pengguna media sosial khususnya terkait dengan UU ITE dan aturan teknis terkait. Penyuluhan dan sosialisasi dimaksud dapat dilakukan secara langsung dan tidak langsung. Dengan semakin majunya era teknologi dan pemanfaatan teknologi pada saat ini dan dalam rangka meminimalkan biaya, maka intensifikasi penyuluhan agar lebih dilakukan secara tidak langsung melalui media di internet antara lain melalui website resmi Pemerintah dan iklan di situs-situs yang memiliki banyak pengunjung seperti situs informasi berita. Dalam rangka meningkatkan efektvifitas atau dampak kegiatan penyuluhan hukum, diperlukan penelitian lebih lanjut mengenai hukum siber di Indonesia terkait sejauh mana pengaturan yang tertuang dalam hukum dimaksud adaptif dengan nilai-nilai sosial masyarakat Indonesia. 


\section{Daftar Pustaka}

\section{Buku-Buku}

Arus Akbar Silondae \& Wirawan B Llyas, Pokok-Pokok Hukum Bisnis, Jakarta : Salemba Empat 2011

C.S.T Kansil, Pengantar Ilmu Hukum dan Tata Hukum Indonesia, Jakarta : Balai Putaka 1986

Eddy OS Hiariej, Prinsip-Prinsip Hukum Pidana, Yogyakarta : Cahaya Atma Pustaka 2014

Johanes Ibrahim \& Lindawati Sewu, Hukum Bisnis (Dalam Persepsi Manusia Modern), Bandunng : Refika Aditama 2003

R. Soesilo, Kitab Undang-Undang Hukum Pidana (KUHP) Serta Komentar-Komentarnya Lengkap Pasal Demi Pasal, Bogor : Politeia, 1995

Rouscoe Pound, "An Introduction to the Philosophy of Law" dalam Romli Atmasasmita, Perbandingan Hukum Pidana, Bandung : Mandar-Maju, 2000

\section{Jurnal-Jurnal}

Asur, Sitaram \& huberman, Bernardo, A. Predicting the Future with Social Media, Web Intelligence and Intelligent Agenct Technology (WI-IAT), Vol. 1, pp492-499

Kietzmann, Jan H, Hermkens, K, McCarthy, I P, Silvestre, Bruno, S, 2011, „Social media? Get serious! Understanding the functional building blocks of social media ${ }^{\text {ee }}$, Business Horizons, Vol. 54, pp241-251

\section{Undang Undang}

\section{KUHP}

KUHAP

Peraturan Menteri Hukum dan Hak Asasi Manusia RI Nomor M.01-PR.08.10 Tahun 2006 tentang Pola Penyuluhan Hukum

Undang-Undang RI No. 11 Tahun 2008 Tentang Informasi dan Teknologi

\section{Sumber Lain}

http://ms.wikipedia.org/wiki/Media_sosial

http://www.google.com/url?q=http://perpustakaan.bphn.go.id/index.php/searchkatalog/downloadDa tabyId/12423/DAMPAKPENYULUHANHUKUMTERHADAPTINGKATKESADARANH UKUMMASYARAKAT.pdf\&sa=U\&ei=20-1VOOKJMq_uASxkYD4Bw\& ved=0CBkQFjAB\&sig2=_PHaL7BcE5mX8rIHlgsibw\&usg=AFQjCNFVWGWH4atfdGLSw Nam9E08A0c_1A

http://ppm.lppm.upi.edu/detail/401/penyuluhan-hukum-dan-ham-untuk-perlindungan-hak-hakperempuan-dalam-rumah-tangga-di-kecamatan-dayeuhkolot-kabupaten-bandung http://www.indosiar.com/fokus/karena-kirim-email-prita-ditahan_80556.html http://news.liputan6.com/read/2098845/florence-sihombing-dan-rinada-ironi-di-dunia-maya 